\title{
Ujaran Kebencian dan Hoaks: Signifikasinya terhadap Pemilih Pemula di Kota Semarang
}

\section{Lusia Astrika}

\author{
Universitas Diponegoro, Semarang
}

\section{Yuwanto}

\section{Universitas Diponegoro, Semarang}

\section{INTISARI}

Artikel ini bertujuan untuk menguji secara empirik korelasi antara prasangka ujaran kebencian (hate speech) dan keyakinan pada hoaks (hoax) dengan sikap politik pemilih pemula di Kota Semarang menjelang Pemilihan Gubernur Jawa Tengah Tahun 2018. Artikel ini berangkat dari penelitian korelasional dengan pendekatan kuantitatif yang menggunakan teknik accidental sampling. Jumlah responden dalam penelitian ini adalah 100 orang, yang merupakan pemilih pemula. Berdasarkan hasil uji hipotesis yang dilakukan, didapatkan hasil bahwa prasangka ujaran kebencian (variabel X1) berpengaruh signifikan terhadap sikap politik pemilih pemula (variabelY), sementara keyakinan pada hoax (variabel X2) berpengaruh tetapi tidak signifikan terhadap sikap politik pemilih pemula (variabel Y). Untuk kesimpulan tersebut, maka saran yang diajukan adalah perlunya sosialisasi pemilu yang baik dan benar dan adanya pendidikan politik yang tepat sangat berguna untuk meminimalisir hoaks dan ujaran kebencian. Dengan cara itu, maka pemilih pemula akan menjadi pemilih yang rasional dan cerdas.

\section{KATA KUNCI}

hoaks; pemilih pemula; pilkada; sikap politik; ujaran kebencian

\section{Korespodensi:}

Departemen Politik dan Pemerintahan, Fakultas IImu Sosial dan IImu Politik, Universitas Diponegoro. Jl. Prof. Soedarto, Tembalang, Kec. Tembalang, Kota Semarang, Jawa Tengah 50139.

Email: lusia.astrika@gmail.com; yuwantosaja@gmail.com 


\section{Pendahuluan}

$\mathrm{D}$ emokrasi memiliki arti dari, oleh, dan untuk rakyat. Dalam proses demokrasi, berlangsung pula proses pemilihan umum (pemilu). Pemilu merupakan pesta demokrasi dan dikenal juga dengan pesta rakyat. Pemilu merupakan bentuk partisipasi politik warga negara, yang bertujuan untuk memilih wakil - wakil rakyat untuk menduduki posisi-posisi penting di pemerintahan (Budiardjo, 2003). Tahun 2018-2019 dikenal luas sebagai tahun politik karena pada tahun ini berlangsung pemilu secara bersamaan untuk memilih kepala daerah (pilkada), pemilihan calon legislatif (pileg), dan pemilihan presiden (pilpres). Pemilu untuk memilih pileg dan pilpres akan digelar pada tanggal 17 April 2019, sementara untuk pilkada serentak akan diselenggarakan pada tanggal 27 Juni 2018. Di lain sisi, pilkada serentak 2018 akan digelar di 171 wilayah, termasuk 17 pemilihan gubernur (pilgub). Pelaksanaan pilkada hanya satu putaran dan tidak ada pemungutan suara ulang terkait perolehan suara (Detik.com, 2018).

Tidak adanya pustara kedua dalam pilkada serentak sesuai dengan aturan dalam Pasal 107 ayat 1 Undang-Undang Republik Indonesia Nomor 10 Tahun 2016 tentang Pemilihan Gubernur, Bupati, dan Walikota atau dikenal dengan sebutan UU Pilkada, menyatakan bahwa:

"Pasangan calon bupati dan calon wakil bupati serta pasangan calon walikota dan calon walikota yang memperoleh suara terbanyak ditetapkan sebagai pasangan Calon Bupati dan Calon Wakil Bupati terpilih serta pasangan calon walikota dan Icalon wakil walikota terpilih."

Hal yang sama ditegaskan dalam Pasal 109 ayat 1 undang-undang yang sama yang menyatakan, "Pasangan calon gubernur dan calon wakil gubernur yang memperoleh suara terbanyak ditetapkan sebagai pasangan calon gubernur dan calon wakil gubernur terpilih".

Persaingan politik untuk mendapatkan suara terbanyak dan memenangkan kompetisi politik dalam Pemilu/ Pilkada/ Pilgub ini tentu saja sangat terasa mulai tahun 2018 ini. Harapannya, setiap peserta pemilu dapat menggunakan cara-cara yang sehat untuk memenangi kompetisi politiknya. Sayangnya, tidak semua peserta menggunakan cara aman dan sehat untuk berkompetisi. Banyak yang kemudian menggunakan cara-cara kotor untuk memenangi pemilu. Salah satunya cara kotor yang digunakan adalah ujaran kebencian (hate speech) yang sudah menjadi satu strategi yang digunakan dalam berpolitik.

Ujaran kebencian adalah semua bentuk ekspresi, verbal atau tertulis, yang menyebarkan, menghasut, mempromosikan atau membenarkan kebencian berdasarkan pada intoleransi atau juga atas dasar agama (Pálmadóttir \& Kalenikova, 2018). Ujaran kebencian ini pada umumnya disebarkan melalui media sosial dan dengan cepat dapat menyebar, sehingga menimbulkan informasi yang keliru, dan pada akhirnya menimbulkan prasangka yang salah. Hal ini terjadi karena negara terlambat memberikan respon melalui regulasi-regulasinya bagi perkembangan teknologi-informasi, terutama media sosial yang menjadi penyemaian berbagai ujaran kebencian (Bank, 2010). 
Strategi kedua yang seringkali dilakukan oleh para peserta politik adalah menyebarkan hoaks atau berita bohong. Hoaks adalah informasi yang sesungguhnya tidak benar, tetapi dibuat seolah-olah benar adanya (Ireton \& Posetti, 2018). Hoaks ini dengan cepat menyebar melalui media sosial seperti facebook, intstagram, whatsapp, twitter, juga media sosial lainnya, dan dengan sengaja disebarkan untuk menjatuhkan lawan politiknya. Hoaks ini berkaitan dengan kepercayaan bahwa berita atau informasi tersebut memang benar adanya. Ini artinya, hoaks sebenarnya merupakan ancaman bagi partisipasi warga dalam proses demokratisasi (Utami, 2018).

Adanya potensi hoaks maupun ujaran kebencian dalam pemilu memiliki dampak signifikan yang mempengaruhi seseorang dalam menentukan pilihannya (Allcott \& Gentzkow, 2017). Untuk itu, munculnya ujaran kebencian dan hoaks dinilai menjadi ancaman bagi generasi muda untuk dapat memilih secara rasional dan cerdas. Hal ini menjadi mengkhawatirkan karena bisa jadi masyarakat akan mempercayai ujaran-ujaran kebencian dan berita bohong, kemudian pada akhirnya mereka memilih calon yang salah atau tidak layak. Kesalahan bisa saja terjadi karena mereka belum memiliki informasi menyeluruh, sehingga dengan mudah mereka berprasangka dan mungkin juga ketidakpercayaan terhadap calon yang diberitakan bohong.

Golongan yang rawan menjadi korban hoaks dan ujaran kebencian tentunya adalah pemilih pemula. Pemilih pemula masuk dalam kategori remaja tahap akhir, usia mereka berkisar dari 17-21 tahun. Pemilih pemula yang baru pertama kali menggunakan hak pilihnya merupakan golongan yang rawan terimbas oleh hoaks dan ujaran kebencian, karena informasi yang mereka terima belum banyak dan mereka juga termasuk dalam kategori usia pencarian jati diri sehingga dengan mudah dipengaruhi oleh sesuatu yang belum tentu benar. Pada usia yang masih remaja, kebutuhan menggunakan media social juga tidak dipungkiri lagi, kebutuhan akan rasa ingin tahu juga menjadi alasan utama penggunaan media social ini. Sebagai generasi penerus bangsa dan agent of change, seharusnya pemilih pemula dapat menggunakan hak pilihnya secara rasional, bukan menjadi pemilih yang irasional karena adanya ujaran kebencian dan hoaks ini.

Untuk itu, artikel ini bertujuan untuk mengetahui hubungan pengaruh prasangka ujaran kebencian dan keyakinan pada hoaks terhadap sikap politik pemilih pemula di Kota Semarang menjelang Pemilihan Gubernur Jawa Tengah tahun 2018. Alasan pemilihan Kota Semarang adalah karena Kota Semarang merupakan ibu kota Provinsi Jawa Tengah, dan pada tanggal 27 Juni 2018 telah berlangsung Pemilihan Gubernur Jawa Tengah. Dalam hal ini, ada dua calon yang maju yaitu pasangan Gandjar Pranowo-Taj Yasin yang mendapatkan nomor urut 1, dan pasangan Sudirman Said-Ida Fauziyah yang mendapatkan nomor urut 2.

Adapun pasangan pertama diusung oleh Partai Demokrasi Indonesia Perjuangan (PDIP), sementara pasangan kedua diusung oleh Partai Gerindra. Keberadaan dua peserta dalam kompetisi pemilihan gubernur Jawa Tengah Tahun 2018 ini pun tidak lepas dari adanya strategi ujaran kebencian dan hoaks. Tidak tanggung-tanggung, setidaknya ada empat media yang terindikasi sering menggunakan pemberitaan bernuansa ujaran kebencian bahkan hoaks (Beritasatu.com, 2018). 
Hal ini membuktikan bahwa ujaran kebencian dan hoaks menjadi ancaman bagi proses demokrasi dan kemajemukan di Indonesia sehingga penting untuk diteliti. Untuk itu, artikel ini berangkat dari penelitian untuk menguji secara empirik pengaruh prasangka ujaran kebencian dan hoaks dengan sikap politik pemilih pemula di Kota Semarang sesaat sebelum Pemilihan Gubernur Jawa Tengah Tahun 2018.

Dalam mengerjakan penelitian ini, penulis menggunakan penelitian korelasional dengan pendekatan kuantitatif. Sesuai dengan tujuan penelitian dan berdasarkan perumusan masalah maka penelitian ini dimaksudkan untuk menerangkan (explanatory atau confirmatory) persoalan, yakni menjelaskan hubungan dan pengaruh antara variabel-variabel yang diteliti melalui pengujian hipotesis secara empiris. Populasi dalam penelitian ini diasumsikan adalah pemilih pemula di Kota Semarang, yang diambil secara acak menggunakan teknik accidental sampling atau disebut juga convenience sampling dari pemilih pemula yang memiliki karakteristik berusia 17 tahun keatas dan merupakan pemilih pemula yang menggunakan hak pilihnya untuk pertama kali pada Pilgub Jawa Tengah Tahun 2018.

Teknik accidental sampling adalah non-probabilitas sampling yang lebih menekankan pada pengambilan kuota dan tidak mengacu pada karakteristik yang tegas (Etikan \& Bala, 2017). Untuk itu, subyek dipilih karena aksesibilitas dan kedekatan mereka dalam proses penelitian. Teknik ini dipilih mengingat jumlah populasi yang terlalu besar sehingga mustahil untuk menyertakan setiap individu. Teknik ini digunakan juga dengan alasan cepat, murah, mudah, dan subyek yang tersedia.

Dalam penelitian ini, sampel diambil dari populasi yang merupakan pemilih pemula di Kota Semarang. Berdasarkan Roscoe dalam Sugiyono (2013) bahwa ukuran sampel lebih dari 30 responden dan kurang dari 500 responden telah mencukupi untuk digunakan dalam sebuah penelitian. Menurut Nazir (2005), jumlah sampel ditetapkan atas pertimbangan pribadi, dengan catatan bahwa sampel tersebut cukup mewakili populasi dengan pertimbangan waktu dan biaya. Oleh karena itu, dengan mengacu pada pendapat Roscoe dan Nazir , maka jumlah sampel dalam penelitian ini sebanyak 100 responden.

Metode pengumpulan data yang digunakan dalam penelitian ini adalah metode skala. Dalam penelitian ini yang dimaksud dengan metode skala adalah suatu metode penyelidikan dengan menggunakan daftar pertanyaan yang harus diisi oleh setiap individu yang akan menjadi subyek penelitian (Ancok, 1985). Penelitian ini menggunakan tiga skala yaitu skala prasangka hate speech, skala kepercayaan pada hoax, dan skala sikap politik pemilih pemula. Dalam penelitian ini koefisien korelasi antara skor item dengan skor total diperoleh dengan tehnik korelasi product moment dari Pearson. Pengujian reliabilitas item-item valid dalam penelitian ini dilakukan dengan menggunakan analisis varians Alpha-Cronbach. Sedangkan untuk pengolahan data akan dilakukan dengan menggunakan program Statistical Packages for Social Sciences (SPSS) for Windows Release 13. Untuk menguji hipotesis mayor, penelitian ini menggunakan tehnik statistik analisis regresi. 
Prasangka ujaran kebencian berarti penilaian yang dilakukan suatu kelompok terhadap kelompok lain atau penilaian terhadap kelompoknya sendiri. Indikator prasangka ujaran kebencian dalam penelitian ini meliputi: perilaku merendahkan intelektual, perilaku merendahkan kultural atau atribut individual, dan perilaku merendahkan moralitas dari individu atau kelompok yang menjadi obyek dari prasangka, serta dilihat juga dari konteks, pelaku, niat, konten, dan tata cara ujaran kebencian.

Keyakinan pada hoaks dalam penelitian ini berarti kepercayaan pada adanya berita bohong. Beberapa indikator yang digunakan dalam penelitian berupa pemikiran, keyakinan, kepercayaan, ide, dan konsep tentang berita yang mengakibatkan kecemasan, kebencian, dan permusuhan, berita yang sumbernya tidak jelas, dan bermuatan fanatisme atau ideologi. Hal ini bisa dijelaskan dalam gambar di bawah ini:

Gambar 2: Kerangka Pemikiran Penelitian

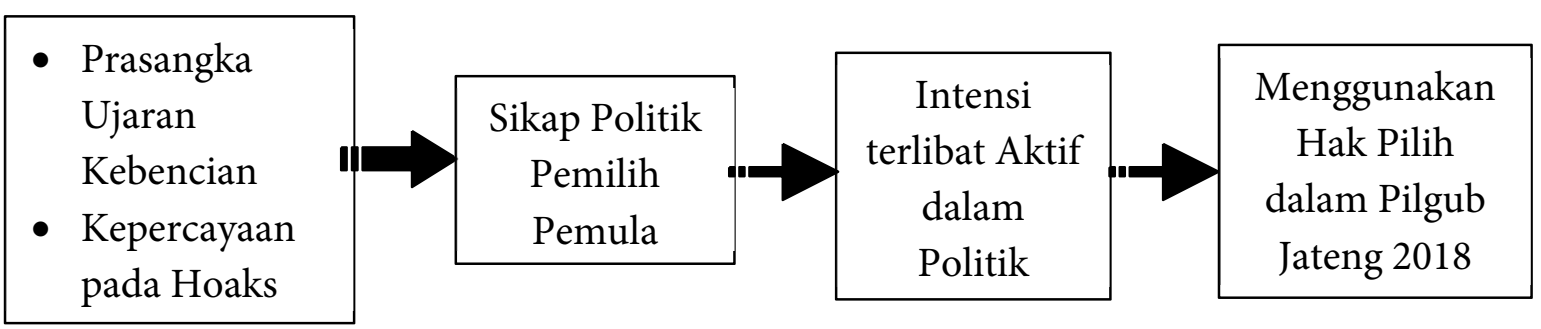

Sumber: Diolah dari Fishbein \& Ajzen (1975)

Dalam Gambar 2 di atas, terlihat jelas bahwa penulis menggunakan definisi sikap yang bersifat unidimensional, yaitu berupa evaluasi positif atau negatif terhadap suatu obyek. Dapat disimpulkan bahwa ada tiga komponen sikap politik pemilih pemula, yaitu: aspek kognitif yang berisi pemikiran, keyakinan, kepercayaan, ide, dan konsep. Aspek afektif yang memuat perasaan atau evaluatif, dan aspek konatif yang merupakan kecenderungan untuk bertindak atau bereaksi terhadap politik.

\section{Menguji Ujaran Kebencian dan Hoaks terhadap Sikap Politik}

Berdasarkan penelitian yang dilakukan, didapatkan analisis deskriptif dari 100 orang responden yang merupakan pemilih pemula, yakni berdasarkan kelompok usia, jenis kelamin, agama, pengetahuan tentang pilgub Jateng 2018. Dari sana, maka bisa diidentifikasi apakah responden akan menggunakan hak pilih, alasan dalam menggunakan hak pilih atau tidak menggunakan hak pilih, dan pendapat tentang hoaks dan ujaran kebencian pada Pilgub Jateng 2018 yang marak di media sosial. Dari 100 responden, 14\% merupakan pemilih pemula berusia 17 - 18 tahun, $78 \%$ merupakan usia $19-20$ tahun, dan $8 \%$ merupakan pemilih yang berusia lebih dari 21 tahun. Adapun sebaran responden adalah $51 \%$ berjenis kelamin perempuan dan 49 \% berjenis kelamin laki-laki dengan komposisi agama sebanyak $79 \%$ responden beragama Islam, 13\% beragama Katholik, 6\% beragama Protestan, $1 \%$ beragama Budha, dan 1 \% beragama Kong Hu Chu. 
Dari 100 responden, seluruh responden 100 \% mengetahui adanya Pilgub Jateng 2018 dan 91 \% diantaranya merupakan responden yang akan menggunakan hak pilihnya pada Pilgub Jateng 2018, sedangkan $9 \%$ responden lainnya memilih untuk tidak menggunakan hak pilihnya. Dari 92 responden yang akan menggunakan hak pilih, 87\% menggunakan hak pilih atas kemauan diri sendiri, 2\% memilih karena diajak saudara, keluarga, atau tetangga, dan $3 \%$ sisanya memilih karena melihat iklan di TV, baliho, atau spanduk. Dari 8 responden yang memilih untuk tidak menggunakan hak pilihnya, 2\% diantaranya tidak memilih karena alasan teknik pemilihan yang rumit, dan 3\% tidak memilih karena kurangnya kepercayaan pada calon, serta 3\% lainnya tidak memilih karena kurangnya sosialisasi.

Dari 92 responden yang menggunakan hak pilih, $24 \%$ akan memilih calon yang berasal dari daerah yang sama, dan 76\% memilih tidak lebih memilih calon yang berasal dari daerah yang sama. Hal ini berarti tidak ada masalah jika calon berasal dari daerah lain. Adapun untuk 92 responden yang memakai hak pilih, $31 \%$ akan memilih calon yang beragama sama, dan 69\% tidak akan memilih calon yang beragama sama. Hal ini berarti agama tidak menjadi faktor penentu bagi pemilih pemula untuk menggunakan pilihannya pada Pilgub Jateng 2018. Di lain sisi, berdasarkan responden yang memakai hak pilih, 34\% responden menyatakan akan memilih calon yang berjenis kelamin sama, dan $66 \%$ menyatakan tidak akan memilih calon yang berjenis kelamin sama. Hal ini berarti jenis kelamin tidak menjadi faktor penentu bagi pemilih pemula untuk menggunakan pilihannya pada Pilgub Jateng 2018.

Dari 92 responden yang akan memilih, 17 \% berpendapat adanya ujaran kebencian dan hoaks tidak akan mempengaruhi sikap politik. Berdasarkan 92 responden tersebut, $72 \%$ menyatakan akan mendukung Pilgub Jateng 2018 jika ujaran kebencian marak di media sosial, dan 28 \% menyatakan tidak akan mendukung Pilgub Jateng 2018 jika ujaran kebencian marak di media sosial. Di lain pihak, responden yang menggunakan hak pilih, sebanyak 79\% menyatakan akan mendukung Pilgub Jateng 2018 jika hoaks marak di media sosial, dan 21 \% menyatakan tidak akan mendukung Pilgub Jateng 2018 jika hoaks marak di media sosial.

Berdasarkan uji hipotesis yang dilakukan dalam penelitian ini diperoleh hasil sebagai berikut:

Gambar 3: Tabel Koefisien Sikap Politik

\begin{tabular}{|c|c|c|c|c|c|}
\hline \multirow[t]{2}{*}{ Model } & \multicolumn{2}{|c|}{$\begin{array}{c}\text { Unstandardized } \\
\text { Coefficients }\end{array}$} & \multirow{2}{*}{$\begin{array}{c}\begin{array}{c}\text { Standardized } \\
\text { Coefficients }\end{array} \\
\text { Beta }\end{array}$} & \multirow[t]{2}{*}{$\mathbf{T}$} & \multirow[t]{2}{*}{ Sig. } \\
\hline & B & Std. Error & & & \\
\hline (Constant) & 30,452 & 4,184 & & 7,279 &, 000 \\
\hline Ujaran Kebencian &, 270 & ,097 & ,287 & 2,771 & ,007 \\
\hline Hoaks & ,035 & , 103 &, 035 & ,337 & ,737 \\
\hline
\end{tabular}


Dengan melihat Gambar 3 di atas, maka terdapat dua hipotesis (Ha) yang diajukan dalam uji t berikut ini:

1) $\mathrm{H} 1=$ Hate Speech (X1) berpengaruh signifikan terhadap Sikap Politik Pemilih Pemula (Y) atau disebut uji t pertama.

2) $\mathrm{H} 2=$ Hoax (X2) berpengaruh signifikan terhadap Sikap Politik Pemilih Pemula (Y) atau disebut uji t kedua.

\section{Uji Hipotesis $\mathbf{H} 1$}

Berdasarkan output koefisien di atas, diketahui bahwa nilai koefisien regresi variabel ujaran kebencian (X1) adalah sebesar 2,771 bernilai positif (+), sehingga dapat dikatakan bahwa ujaran kebencian (X1) berpengaruh positif terhadap sikap politik Pemilih Pemula (Y). Pengaruh positif diartikan bahwa semakin meningkat ujaran kebencian (X1) maka akan meningkat pula sikap politik pemilih pemula (Y). Selanjutnya, untuk mengetahui apakah pengaruh tersebut signifikan atau tidak, maka nilai kooefisien regresi variabel ujaran kebencian (X1) ini akan diuji signifikansinya (uji t Parsial). Hipotesis dalam uji t pertama adalah:

1) $\mathrm{H} 0=$ Hate Speech (X1) tidak berpengaruh signifikan terhadap Sikap Politik Pemilih Pemula (Y)

2) $\mathrm{H} 1=$ Hate Speech (X1) berpengaruh signifikan terhadap Sikap Politik Pemilih Pemula (Y)

Untuk menguji hipotesis di atas, maka tingkat kepercayaan yang digunakan adalah 95\%, maka nilai $\alpha=0,05$ dan dasar pengambilan keputusan dalam uji t pertama:

- H0 diterima dan H1 ditolak jika nilai thitung $<\mathrm{t}$ tabel atau jika nilai Sig. > 0,05

- H0 ditolak dan H1 diterima jika nilai thitung $>\mathrm{t}$ tabel atau jika nilai Sig. < 0,05

$\mathrm{t}$ tabel $=$ tingkat kepercayaan dibagi 2 ; jumlah responden dikurangi jumlah variabel bebas dikurangi 1

t tabel $=(\alpha / 2 ; n-k-1)$

$\mathrm{t}$ tabel $=(0,05 / 2 ; 100-2-1)$

t tabel $=(0,025 ; 97)$

$\mathrm{t}$ tabel $=$ angka 0,$025 ; 97$ kemudian di cari pada distribusi nilai $\mathrm{t}$ tabel maka ditemukan nilai $\mathrm{t}$ tabel sebesar 1,985

Berdasarkan hasil analisis regresi yang telah diolah dari data yang ada, maka diperoleh:

t hitung $=2,771 \quad$ thitung $>$ t tabel

$2,771>1,985$

Sig. $=0,007 \quad$ Sig. $<0,05$

$0,007<0,05$ 
Dari sini, maka dapat disimpulkan bahwa H0 ditolak dan H1 diterima, yang artinya ujaran kebencian (X1) memiliki pengaruh signifikan terhadap sikap politik pemilih pemula (Y).

\section{Uji Hipotesis $\mathrm{H} 2$}

Berdasarkan output koefisien di atas, diketahui bahwa nilai koefisien regresi variabel Hoaks (X2) adalah sebesar 0,337 bernilai positif (+), sehingga dapat dikatakan bahwa Hoaks (X2) berpengaruh positif terhadap sikap politik pemilih pemula (Y). Pengaruh positif diartikan, bahwa semakin meningkat hoaks (X2) maka akan meingkat pula sikap politik pemilih pemula (Y). Selanjutnya, untuk mengetahui apakah pengaruh tersebut signifikan atau tidak, maka nilai kooefisien regresi variabel hoaks (X2) ini akan diuji signifikansinya (uji t Parsial). Hipotesis dalam uji t pertama adalah:

1) $\mathrm{H} 0=$ Hoaks (X2) tidak berpengaruh signifikan terhadap Sikap Politik Pemilih Pemula (Y)

2) H1 = Hoaks (X2) berpengaruh signifikan terhadap Sikap Politik Pemilih Pemula (Y)

Untuk menguji hipotesis di atas, maka tingkat kepercayaan yang digunakan adalah 95\%, maka nilai $\alpha=0,05$ dan dasar pengambilan keputusan dalam uji t pertama:

- H0 diterima dan H1 ditolak jika nilai thitung < t tabel atau jika nilai Sig. $>$ 0,05

- H0 ditolak dan H1 diterima jika nilai thitung $>\mathrm{t}$ tabel atau jika nilai Sig. $<0,05$

$\mathrm{t}$ tabel $=($ tingkat kepercayaan dibagi 2 ; jumlah responden dikurangi jumlah variabel bebas dikurangi 1$)$

$\mathrm{t}$ tabel $=(\alpha / 2 ; \mathrm{n}-\mathrm{k}-1)$

$\mathrm{t}$ tabel $=(0,05 / 2 ; 100-2-1)$

$\mathrm{t}$ tabel $=(0,025 ; 97)$

$\mathrm{t}$ tabel $=$ angka 0,$025 ; 97$ kemudian di cari pada distribusi nilai $\mathrm{t}$ tabel maka ditemukan nilai $\mathrm{t}$ tabel sebesar 1,985

Berdasarkan hasil analisis regresi yang telah diolah dari data yang ada, maka diperoleh:

$\mathrm{t}$ hitung $=0,337 \quad \mathrm{t}$ hitung $<\mathrm{t}$ tabel

$0,337<1,985$

Sig. $=0,737 \quad$ Sig. $>0,05$

$0,737>0,05$

Dari hasil di atas, maka dapat disimpulkan bahwa H0 diterima dan H1 ditolak, yang artinya Hoax (X2) berpengaruh tapi tidak signifikan terhadap Sikap Politik Pemilih Pemula (Y).

\section{Uji F (F test)}

Uji F (F test) dilakukan untuk mengetahui pengaruh variabel bebas secara bersama-sama (simultan) terhadap variabel terikat. Dasar pengambilan keputusan untuk uji $\mathrm{F}$ adalah dengan melihat F hitung dan F tabel sebagai berikut: 
- Jika nilai F hitung > F tabel maka variabel independen (bebas) secara simultan berpengaruh terhadap variabel dependen (terikat).

- Jika nilai F hitung < F tabel maka variabel independen (bebas) secara simultan tidak berpengaruh terhadap variabel dependen (terikat).

Selain itu didasarkan pula pada hasil perhitungan uji F berdasarkan nilai signifikansi hasil output SPSS sebagai berikut:

- Jika nilai signifikansi < 0,05, maka variabel independen secara bersama-sama berpengaruh signifikan terhadap variabel dependen.

- Jika nilai signifikansi > 0,05, maka variabel independen secara bersama-sama tidak berpengaruh signifikan terhadap variabel dependen.

Gambar 4: Analisis ANOVA ${ }^{a}$

\begin{tabular}{|l|r|r|r|r|r|}
\hline \multicolumn{1}{|c|}{ Model } & \multicolumn{1}{c|}{$\begin{array}{c}\text { Sum of } \\
\text { Squares }\end{array}$} & \multicolumn{1}{c|}{ df } & $\begin{array}{c}\text { Mean } \\
\text { Square }\end{array}$ & \multicolumn{1}{c|}{ F } & \multicolumn{1}{c|}{ Sig. } \\
\hline Regression & 81,819 & 2 & 40,909 & 4,858 &, $010^{\mathrm{b}}$ \\
\hline Residual & 816,771 & 97 & 8,420 & & \\
\hline Total & $\mathbf{8 9 8 , 5 9 0}$ & $\mathbf{9 9}$ & & & \\
\hline
\end{tabular}

a. Dependent Variable: SIKAP POLITIK

b. Predictors: (Constant), HOAX, HATE SPEECH

Dari output di atas, diperoleh nilai F hitung sebesar 4,858, sedangkan untuk mencari nilai F tabel menggunakan rumus berikut:

$\mathrm{F}$ tabel $=($ jumlah variabel bebas $;$ jumlah responden - jumlah variabel bebas $)$

$\mathrm{F}$ tabel $=(\mathrm{k} ; \mathrm{n}-\mathrm{k})$

F tabel $=(2 ; 100-2)$

F tabel $=(2 ; 98)$

$\mathrm{F}$ tabel pada angka $(2 ; 98)$ menghasilkan nilai $\mathrm{F}$ tabel $=3,09$

F hitung $=4,858 \quad$ F hitung $>$ F tabel

$4,858>3,09$

Sig. $=0,010 \quad$ Sig. $<0,05$

$0,010<0,05$

Dari uji F di atas, maka dapat disimpulkan bahwa Uji F dilakukan untuk mengetahui pengaruh variabel bebas secara bersama-sama (simultan) terhadap variabel terikat. Dalam melihat penjabaran tersebut, maka pengambilan keputusan dalam uji F baik itu membandingkan nilai F hitung dan nilai 
F tabel, maupun berpedoman pada nilai signifikansi diperoleh hasil yang sama pula atau hasil yang konsisten.

Hal ini menunjukkan bahwa dalam penelitian ini, sumbangan efektif dan pengaruh yang paling besar adalah ujaran kebencian dibandingkan dengan hoaks. Karena ujaran kebencian lebih pada prasangka yang memainkan aspek kognitif dibandingkan dengan afektif. Sementara keyakinan pada hoaks lebih memainkan unsur afektifnya. Jika dihubungkan dengan analisis deskriptif responden, dimana mereka memilih tidak berdasarkan pada agama, jenis kelamin, dan kesamaan tempat tinggal yang sama dengan calon, maka alasan memilih adalah karena pertimbangan rasional yang mereka buat. Dalam hal ini, pemikiran secara kognitif lebih signifikan dibanding faktor lainnya. Semakin rasional seseorang dalam menggunakan hak pilihnya (secara kognitif) maka semakin positif sikap politik pemula di Kota Semarang menjelang pemilihan Gubernur Jawa Tengah Tahun 2018. Semakin maraknya ujaran kebencian justru akan membuat pemilih pemula banyak berpikir secara kognitif sehingga mereka akan justru mendukung berlangsungnya pemilihan Gubernur Jawa Tengah Tahun 2018.

\section{Penutup}

Dari apa yang telah dipaparkan sebelumnya, maka didapatkan kesimpulan penting bahwa prasangka ujaran kebencian (X1) berpengaruh positif terhadap sikap politik pemilih pemula (Y), dimana pengaruh positif diartikan bahwa semakin meningkat prasangka ujaran kebencian (X1) maka akan meningkat pula sikap politik pemilih pemula (Y). Selain itu, ditemukan bahwa ada pertimbangan rasional pemilih pemula di Kota Semarang menjelang Pilgub Jateng 2018 dalam menentukan sikap politiknya ditinjau dari prasangka hate speech dan keyakinan terhadap hoax.

Untuk itu, supaya ujaran kebencian dan hoaks tidak menjadi preferensi seseorang dalam menentukan pilihan, maka penulis memiliki beberapa rekomendasi yang bisa dikerjakan. Pertama, pemilih pemula disarankan untuk mencari kebenaran dari setiap berita yang diperoleh, dengan mencari sumber yang benar, sehingga tidak mudah dibohongi dan tidak mudah yakin atau percaya dengan adanya hoaks. Kedua, pemilih pemula seharusnya mempertimbangkan secara rasional setiap berita atau isu yang berbau SARA dan juga berita yang mengandung unsur ujaran kebencian. Ketigam sosialisasi pemilu yang baik dan benar dan adanya pendidikan politik yang tepat sangat berguna untuk meminimalisir/ menangkal hoax dan hate speech, dengan begitu pemilih pemula akan menjadi pemilih yang rasional dan cerdas.

\section{Ucapan Terima Kasih}

Terima kasih kepada Susanto yang telah membantu dalam proses coding dan olah data selama proses riset berlangsung. 


\section{Pendanaan}

Artikel ini dikerjakan dengan bantuan pendanaan dari dana DIPA Fakultas Ilmu Sosial dan Ilmu Politik Universitas Diponegoro Tahun 2018.

\section{Daftar Pustaka}

Allcott, H., \& Gentzkow, M. (2017). Social media and fake news in the 2016 election. Journal of Economic Perspectives, 31(2), 211-236. Diunduh dari https://web.stanford.edu/ gentzkow/ research/fakenews.pdf

Ancok, D. (1985). Tehnik Penyusunan Skala Pengukuran. Yogyakarta: Pusat Penelitian Kependudukan Universitas Gadjah Mada.

Bank, J. (2010). Regulating hate speech online. International Review of Law, Computers e Technology, 24(3), 233-239. https://doi.org/10.1080/13600869.2010.522323

Beritasatu.com. (2018). Diduga Sebarkan Hoax Pilgub Jateng, 4 Media Dipolisikan. Diakses pada 10 Maret 2018, dari https:/www.beritasatu.com/nasional/483997/diduga-sebarkan-hoax-pilgubjateng-4-media-dipolisikan

Budiardjo, M. (2003). Dasar-Dasar Ilmu Politik. Jakarta: Gramedia Pustaka Utama.

Detik.com. (2018). Catat! Tak Ada Putaran Kedua di Pilkada Serentak 2018. Diakses pada 22 Maret 2018, dari https://news.detik.com/berita/d-3810605/catat-tak-ada-putaran-kedua-di-pilkadaserentak-2018

Etikan, I., \& Bala, K. (2017). Sampling and Sampling Methods. Biometrics and Biostatistics International Journal, 5(6). https://doi.org/10.15406/bbij.2017.05.00149

Fishbein, M., \& Ajzen, I. (1975). Belief, attitude, intention, and behavior: an introduction to theory and research. Massachusetts: Addison-Wesley Pub. Co.

Ireton, C., \& Posetti, J. (2018). Journalism, fake news \& disinformation: handbook for journalism education and training. UNESCO Publishing.

Nazir, M. (2005). Metode Penelitian. Jakarta: Ghalia Indonesia.

Pálmadóttir, J. A., \& Kalenikova, I. (2018). Hate speech: An overview and recommendations for combating it. Iceland Human Right Center. Diunduh dari http://www.humanrights.is/static/ files/Skyrslur/Hatursraeda/hatursraeda-

Sugiyono. (2013). Metode Penelitian Pendidikan Kuantitatif, Kualitatif dan R\&D. Bandung: Alfabeta.

Undang-Undang Republik Indonesia Nomor 10 Tahun 2016 tentang Pemilihan Gubernur, Bupati, dan Walikota. (2016). Jakarta: Pemerintah Republik Indonesia. Diunduh dari https://mkri.id/ public/content/jdih/UU_Nomor_10_Tahun_2016.pdf

Utami, P. (2018). Hoax in Modern Politics: The Meaning of Hoax in Indonesian Politics and Democracy. Jurnal Ilmu Sosial Dan Ilmu Politik, 22(2), 2018. https://doi.org/10.22146/jsp.34614 


\section{Tentang Penulis}

Lusia Astrika adalah dosen Departemen Politik dan Pemerintahan, Fakultas Ilmu Sosial dan Ilmu Politik, Universitas Diponegoro, dengan area riset seputar perilaku dan psikologi politik.

Yuwanto adalah dosen Departemen Politik dan Pemerintahan, Fakultas Ilmu Sosial dan Ilmu Politik, Universitas Diponegoro, Universitas Diponegoro, dengan area riset tentang ekonomi politik Asia Timur dan perbandingan kebijakan. 